\title{
An improved assay for rapid detection of viable Staphylococcus aureus cells by incorporating surfactant and PMA treatments in $\mathrm{qPCR}$
}

\author{
Chen $\mathrm{Zi}^{1+}$, Dexin Zeng ${ }^{1+}$, Nan Ling ${ }^{1+}$, Jianjun Dai ${ }^{1}$, Feng Xue ${ }^{1 *}$, Yuan Jiang ${ }^{1,2}$ and Baoguang $\mathrm{Li}^{3}$ (D)
}

\begin{abstract}
Background: Staphylococcus aureus is an important human pathogen causing a variety of life-threatening diseases. Rapid and accurate detection of Staphylococcus aureus is a necessity for prevention of outbreaks caused by this pathogen. PCR is a useful tool for rapid detection of foodborne pathogens, however, its inability to differentiate DNA from dead cells and live cells in amplification severely limits its application in pathogen detection. The aim of this study was to develop an improved assay was developed by incorporating the sample treatments with a surfactant and propidium monoazide (PMA) in QPCR for detection of viable S. aureus cells.

Results: The cell toxic effect testing with the two surfactants showed that the viability of $S$. aureus was virtually not affected by the treatment with $0.5 \%$ triton $x-100$ or $0.025 \%$ sarkosyl. Triton $x-100$ was coupled with PMA for sample treatments for detection of viable $S$. aureus cells in artificially contaminated milk. The qPCR results indicated that the assay reached high an amplification efficiency of $98.44 \%$ and the live $S$. aureus cells were accurately detected from the triton-treated spiked milk samples by the PMA-qPCR assay.

Conclusions: The qPCR assay combined with treatments of PMA and surfactants offers a sensitive and accurate means for detection of viable $S$. aureus cells. Cell toxic effect testing with the two surfactants showed that the viability of S. aureus was virtually not affected by the treatment with $0.5 \%$ triton $\mathrm{x}-100$ or $0.025 \%$ sarkosyl. The information on sample treatment with surfactants to improve the dead cell DNA removal efficiency in qPCR by increasing PMA's permeability to dead cells can be used for other pathogens, especially for Gram-positive bacteria.
\end{abstract}

Keywords: Staphylococcus aureus, PMA-qPCR, Sarkosyl, Triton x-100, Accurate detection, Viability, False positive, Milk, Methicillin-resistant Staphylococcus aureus

\section{Background}

Staphylococcus aureus, a Gram-positive bacterium, is an important human pathogen causing various life-threatening infections [1]. Antibiotic resistance resulted from long-term use and misuse of antibiotics causes people to be sick for longer and increases the risk of death. Methicillin-resistant Staphylococcus aureus (MRSA) is an important and growing cause of staphylococcal infection

\footnotetext{
* Correspondence: fengxue1219@aliyun.com

${ }^{\dagger}$ Chen Zi, Dexin Zeng and Nan Ling contributed equally to this work.

${ }^{1} \mathrm{MOE}$ Joint International Research Laboratory of Animal Health and Food

Safety, College of Veterinary Medicine, Nanjing Agricultural University,

Nanjing 210095, China

Full list of author information is available at the end of the article
}

[2-4]. A report from World Health Organization (WHO) showed that it is $64 \%$ more likely to die for people infected by MRSA than those by non-resistant form [5]. Thus, it is imperative to have to ample availability of methodologies for rapid and accurate detection of $S$. aureus to protect the food supply chain and curtail misuse of antibiotics.

PCR has become a common and useful technology in detection of foodborne pathogens and greatly enhanced the efficiency of pathogen detection. However, DNA can persist for long period of time in the environment even after cells' death; and the residual DNA could not be completely eliminated by high temperature $\left(121^{\circ} \mathrm{C}\right.$ for $15 \mathrm{~min}$ ) [6]. Consequently, the DNA from the dead cells

(c) The Author(s). 2018 Open Access This article is distributed under the terms of the Creative Commons Attribution 4.0 International License (http://creativecommons.org/licenses/by/4.0/), which permits unrestricted use, distribution, and 
may be amplified in PCR reaction. Thus, PCR's inability to differentiate DNA from dead cells and live cells in amplification constitutes a serious drawback to its application in pathogen detection [7].

To remedy this shortcoming of PCR, there are a few options. One practical approach is the use of a biological dye, propidium monoazide (PMA) [7]. Treatment of cells with ethidium monoazide (EMA) or PMA (a derivative of EMA) has been used in conjunction with qPCR (EMA/PMA-qPCR) to distinguish live and dead cells using membrane integrity as viability criterion [8]. The viability discrimination is based on the characteristics of the dyes: EMA and PMA. EMA or PMA is positively charged molecule, and thus is excluded by intact, negatively charged bacterial cell-membranes, but can enter bacteria with compromised cell-membranes. When they selectively enter the compromised cells, the dye intercalates into nucleic acids and forms a covalent modification between the dye and DNA after exposure to bright visible light [9]. Thus, PCR can preferentially amplify the DNA of viable cells. Researchers have showed that PMA was more selective than EMA in inhibiting DNA amplification from dead cells [10]. PMA has been widely used in conjunction with PCR to limit false-positive PCR results in detection of foodborne pathogens, especially with Gram-negative bacteria such as Escherichia coli, Salmonella [10, 11]. However, little is known about PMA's permeability to the cell-membranes of dead S. aureus cells. It has shown that detergents can improve PMA or EMA's permeability to dead cells without compromising the viability of live cells [12]. Sarkosyl, a surfactant, has been used for dissipation of PMA-barrier properties of membranes of inactivated $E$. coli cells [13]; and triton $\mathrm{x}-100$, another surfactant, has been tried to increase the permeability of bacteria. In this study, we evaluated the efficiency of the two surfactants in improving PMA's permeability to dead S. aureus cells and combined the surfactant and PMA treatments with qPCR to improve the dead cell DNA removal efficiency. Moreover, we have applied the PMA-qPCR for rapid and accurate detection of live $S$. aureus cells in spiked milk.

\section{Methods}

\section{Bacterial strains and culture conditions}

The S. aureus (ATCC25923), a reference strain used throughout the study, was inoculated in Luria Bertani (LB) and incubated at $37{ }^{\circ} \mathrm{C}$ shaking for $18 \mathrm{~h}$. The bacterial culture was centrifuged at $8000 \times \mathrm{g}$ for $10 \mathrm{~min}$ and washed thrice with phosphate buffered saline (PBS), then the bacteria were resuspended in PBS. The bacterial cells were diluted 10 -fold (up to $10^{7}$ ) and plated onto LB agar plates for viable cell count. The diluted cell suspensions were equally divided into two sets of aliquots. One set of the aliquots was heated at $100{ }^{\circ} \mathrm{C}$ for $20 \mathrm{~min}$ for dead cells, and the other set was not heated for live cells. All other strains used in the inclusivity and exclusivity tests were grown in the same conditions as the strain of $S$. aureus (ATCC25923) and listed in Table 1.

\section{Sample treatments with triton $\mathrm{x}-100$ and sarkosyl}

To test the cell toxicity of triton $\mathrm{x}-100$ and sarkosyl to $S$. aureus cells, different concentrations of the two surfactants $(0.1 \%, 0.25 \%, 0.5 \%$, and $2 \%$ triton $\mathrm{x}-100 ; 0.005 \%$, $0.025 \%, 0.05 \%$, and $0.25 \%$ sarkosyl) were added to $1 \mathrm{ml}$ of bacterial suspension as shown in Table 2. After incubation at $37{ }^{\circ} \mathrm{C}$ for $20 \mathrm{~min}$, the treated bacteria were 10 -fold serially diluted. The cell dilutions were plated onto LB agar plates and incubate at $37{ }^{\circ} \mathrm{C}$ for $18 \mathrm{~h}$ for viable cell count.

\section{Optimization of PMA concentration for cell treatment}

Based on the effect of surfactant treatment to the viability of $S$. aureus cells, bacterial cells were treated with appropriate concentration of two surfactants $(0.5 \%$ triton $\mathrm{x}-100$ or $0.025 \%$ sarkosyl) for $20 \mathrm{~min}$. Then, the cells were treated with PMA (Biotium, USA). PMA was dissolved in DMSO to $10 \mathrm{mM}$ solution and stored at $-20^{\circ}$. To determine the optimal concentration for PMA treatment, different concentrations of PMA $(1,4,10,40$, and $100 \mu \mathrm{M})$ were tested. Briefly, $1 \mathrm{ml}$ of $S$. aureus cells $\left(10^{6} \mathrm{CFU} / \mathrm{ml}\right)$ were incubated with different concentrations of PMA for $5 \mathrm{~min}$ in the dark, and then the cells were exposed to an intensive light source (BLU-V System, Qiagen, Germany) for $15 \mathrm{~min}$. The bacteria were collected by centrifugation at $8000 \times \mathrm{g}$ for $10 \mathrm{~min}$, and then proceeded for DNA extraction with a TIANamp bacterial DNA kit (Tiangen Biotech).

\section{Setting the qPCR assay conditions}

Primers and TaqMan probe were designed based on the sequences of GenBank (Accession number, CP019563.1) using Primer Premier 5.0 program (forward primer, TTCGCTACTAGTTGCTTA; reverse primer, GCAC TATATACTGTTGGATC; and probe, FAM-TCAGAACC ACTTCTATTTACGCCGT-TAMARA). The expected length of PCR amplicon was $124 \mathrm{bp}$. The PCR reaction mix was consisted of $10.0 \mu \mathrm{l}$ of Premix Ex Taq Master Mix (Takara, Dalian, China), $200 \mathrm{nM}$ forward and reverse primers, $200 \mathrm{nM}$ probe, $200 \mathrm{nM}$ ROX Reference Dye II (Takara, Dalian, China), $5 \mu \mathrm{l}$ of template DNA, and $3.4 \mu \mathrm{l}$ of water to make up $20 \mu \mathrm{l}$ as the final reaction volume. The qPCR amplification was initially started at $95{ }^{\circ} \mathrm{C}$ for $15 \mathrm{~s}$, then $95{ }^{\circ} \mathrm{C}$ for $5 \mathrm{~s}$, and followed by $62{ }^{\circ} \mathrm{C}$ for $34 \mathrm{~s}$ (40 cycles). SPSS Statistics 17.0 (software) was used to analyze significant difference between different groups by the method of General Linear Model (GLM). 
Table 1 Bacterial strains used for the inclusivity and exclusivity tests in this study

\begin{tabular}{|c|c|c|c|}
\hline Bacterial species & Strain & Source & Detection result by qPCR \\
\hline \multirow[t]{21}{*}{ Staphylococcus aureus $(n=20)$} & ATCC 25923 & ATCC $^{a}$ & + \\
\hline & SA1011 \# & Flour product & + \\
\hline & SA1012 \# & Pork & + \\
\hline & SA1013 \# & Frozen corn & + \\
\hline & SA1014 \# & Raw milk & + \\
\hline & SA1015 \# & Raw milk & + \\
\hline & SA1016 \# & Raw milk & + \\
\hline & SA1017 \# & Human (sputum) & + \\
\hline & SA1018 \# & Human (blood) & + \\
\hline & SA1019 \# & Human (pus) & + \\
\hline & SA1020 \# & Human (wound) & + \\
\hline & SA1131 \# & Human (sputum) & + \\
\hline & SA1132\# & Flour product & + \\
\hline & SA1133\# & Pork & + \\
\hline & SA1134 \# & Frozen corn & + \\
\hline & SA1135 \# & Raw milk & + \\
\hline & SA1136 \# & Pig & + \\
\hline & SA1137 \# & Pork & + \\
\hline & SA1138\# & Pig & + \\
\hline & SA1139 \# & Raw milk & + \\
\hline & SA1140 \# & Raw milk & + \\
\hline Salmonella Typhimurium & ATCC 14028 & ATCC & - \\
\hline Salmonella Typhimurium & CICC21484 & $\mathrm{ClCC}^{\mathrm{b}}$ & - \\
\hline Salmonella Enteritidis & ClCC24119 & $\mathrm{ClCC}$ & - \\
\hline Escherichia coli & ATCC 25922 & ATCC & - \\
\hline Listeria monocytogenes & CMCC54002 & $\mathrm{CMCC}^{\mathrm{C}}$ & - \\
\hline Listeria grayi & ATCC 25401 & ATCC & - \\
\hline Listeria seeligeri & ATCC 35967 & ATCC & - \\
\hline Listeria welshimeri & ATCC 35897 & ATCC & - \\
\hline \multirow[t]{7}{*}{ Listeria ivanovii $(n=7)$} & ATCC 19119 & ATCC & - \\
\hline & CMCC89001 & CMCC & - \\
\hline & VP61 \# & Human (anal swab) & - \\
\hline & VP65 \# & Restaurant & - \\
\hline & VP67 \# & Trout & - \\
\hline & VP105 \# & Bass & - \\
\hline & VP106 \# & Clams & - \\
\hline Vibrio parahemolyticus & VP108 \# & Cuttlefish & - \\
\hline Streptococcus hemolyticus & ATCC 21059 & ATCC & - \\
\hline \multirow[t]{4}{*}{ Campylobacter jejuni $(n=4)$} & ATCC 33291 & ATCC & - \\
\hline & ATCC 43464 & ATCC & - \\
\hline & CJ2 \# & Human & - \\
\hline & CJ12 \# & Chicken & - \\
\hline Clostridium perfringens & ATCC 13124 & ATCC & - \\
\hline Bacillus cereus & ATCC 11778 & ATCC & - \\
\hline
\end{tabular}


Table 1 Bacterial strains used for the inclusivity and exclusivity tests in this study (Continued)

\begin{tabular}{llll}
\hline Bacterial species & Strain & Source & Detection result by qPCR \\
\hline Pseudomonas aeruginosa & ATCC 27853 & ATCC & - \\
\hline
\end{tabular}

${ }^{a}$ ATCC refers to American Type Culture Collection, USA

${ }^{\mathrm{b}} \mathrm{CVM}-\mathrm{NAU}$ refers to College of Veterinary Medicine, Nanjing Agricultural University, Nanjing, China

${ }^{\mathrm{C} C M C C}$ refers to National Center for Medical Culture, China

\section{Sensitivity test}

A serial of 10 -fold dilution $\left(10^{1}-10^{6}\right)$ of $S$. aureus cell culture was made, and DNA extraction of different dilution was performed with a TIANamp bacterial DNA kit. The resultant DNA was analyzed by qPCR.

\section{Inclusivity and exclusivity tests}

$S$. aureus strains $(n=21)$, including the reference strain (ATCC25923) were tested for inclusivity test. The exclusivity test covered non-S. aureus strains $(n=30)$, including common foodborne pathogens (Table 1 ).

\section{Detection of live cells in mixture of live and dead cells} Dead S. aureus cells $\left(10^{5}\right)$ were mixed with $10^{2}, 10^{3}, 10^{4}$, and $10^{5}$ viable cells, respectively, and $0.5 \%$ triton $\mathrm{x}-100$ was also added into each sample. The cell mixtures were split equally into two aliquots. One set of the aliquots was treated with $40 \mu \mathrm{M}$ PMA, and the other set was not treated. After the PMA treatment, both the PMA-treated and untreated cell mixtures were subjected to DNA extraction. Subsequently, the DNA was analyzed by qPCR as mentioned about.

\section{Detection of viable cells of $S$. aureus in spiked milk}

To assess the ability of the PMA-qPCR assay in distinguishing viable and dead cells in food, we applied this assay for detection of viable $S$. aureus cells in spiked milk. Pasteurized whole milk was purchased from a local food market and confirmed to be free of S. aureus. Each milk sample $(1 \mathrm{ml})$ was mixed with $1.0 \times 10^{4}$ dead $S$. aureus cells and different amount of live $S$. aureus cells $\left(10^{2}, 10^{3}, 10^{4}, 10^{5}\right.$, and $\left.10^{6} \mathrm{CFU} / \mathrm{ml}\right)$, respectively. Each concentration was sampled in triplicate. Then the spiked milk samples were centrifuged at $8000 \times \mathrm{g}$ for $10 \mathrm{~min}$, and the cream and liquid in the tube were removed. The cell pellets were washed three times with $\mathrm{PBS}$, and then $1 \mathrm{ml}$ of PBS with $0.5 \%$ triton $\mathrm{x}-100$ was used to resuspend the pellets. The cell resuspensions were incubated at $37{ }^{\circ} \mathrm{C}$ for $20 \mathrm{~min}$. The cell samples were treated with $40 \mu \mathrm{M}$ of PMA in the dark and exposed to intensive light. DNA extraction and PMA-qPCR were performed in the same methods as mentioned above. The live cell control was treated in the same way except that no PMA was used.

\section{Statistical analysis}

All statistical analyses were performed using SPSS17.0 software.

\section{Results}

Sensitivity and specificity of the qPCR assay

The qPCR assay generated a standard curvet with a slope of -3.16 and amplification efficiency of $100.36 \%$. The $\mathrm{R}^{2}$ is extremely close to 1.0 , presenting a robust PCR amplification (Fig. 1). The result of qPCR assay with the serially diluted cell suspension showed a $\mathrm{Cq}$ value of 37.36 on the sample of $5.0 \times 10^{1} \mathrm{~S}$. aureus cells.

All the $S$. aureus strains tested $(n=21)$ were positively detected by the qPCR assay; and all the non-S. aureus strains tested $(n=30)$ were shown negative and no cross-reactivity was detected with the non-S. aureus strains (Table 1).

\section{Cells treated with different concentrations of triton $x-100$ and sarkosyl}

The two surfactants (triton $\mathrm{x}-100$ and sarkosyl) used to treat $S$. aureus cells in this study demonstrated various degrees of effect to the cell viability by different concentration of surfactants as shown in Table 2. For example, the viability of $S$. aureus cells treated with triton $\mathrm{x}-100$ was not affected when the concentration was $0.5 \%$ or less $(0.1 \%, 0.25$, and 0.5$)$, while the cell viability was significantly affected $(P<0.01)$ by $2 \%$ triton $x-100$ (Table 2). Similarly, different concentration of sarkosyl demonstrated various degrees of effect on the cell viability. For example, a vast majority of the cells lost viability when treated with either $0.05 \%$ or $0.25 \%$ sarkosyl for $20 \mathrm{~min}$; however, there was negligible effect to the cell viability when the concentration of sarkosyl was $0.025 \%$ or less (Table

Table 2 Toxic effect of the cell treatment with two surfactants to live S. aureus cells assessed by colony count

\begin{tabular}{|c|c|c|c|c|c|c|c|c|c|}
\hline \multirow[t]{2}{*}{ Surfactant } & \multicolumn{4}{|c|}{ Triton $\mathrm{x}-100$ concentration $(\mathrm{v} / \mathrm{v})$} & \multicolumn{4}{|c|}{ Sarkosyl concentration (m/v) } & \multirow[t]{2}{*}{ NC } \\
\hline & $0.10 \%$ & $0.25 \%$ & $0.50 \%$ & $2 \%$ & $0.005 \%$ & $0.025 \%$ & $0.05 \%$ & $0.25 \%$ & \\
\hline $\mathrm{CFU} / \mathrm{mL}^{\mathrm{a}}$ & $4.64 \times 10^{6}$ & $4.68 \times 10^{6}$ & $4.63 \times 10^{6}$ & $3.57 \times 106^{b}$ & $4.77 \times 10^{6}$ & $4.62 \times 10^{6}$ & $1.57 \times 10^{5}$ & $1.02 \times 10^{3}$ & $4.4 \times 10^{6}$ \\
\hline
\end{tabular}

${ }^{a}$ refers to the mean of colony counts in three plates

bold-faced number refers to a significant difference $(p<0.01)$ compared to the negative control $(\mathrm{NC})$ or PBS control 


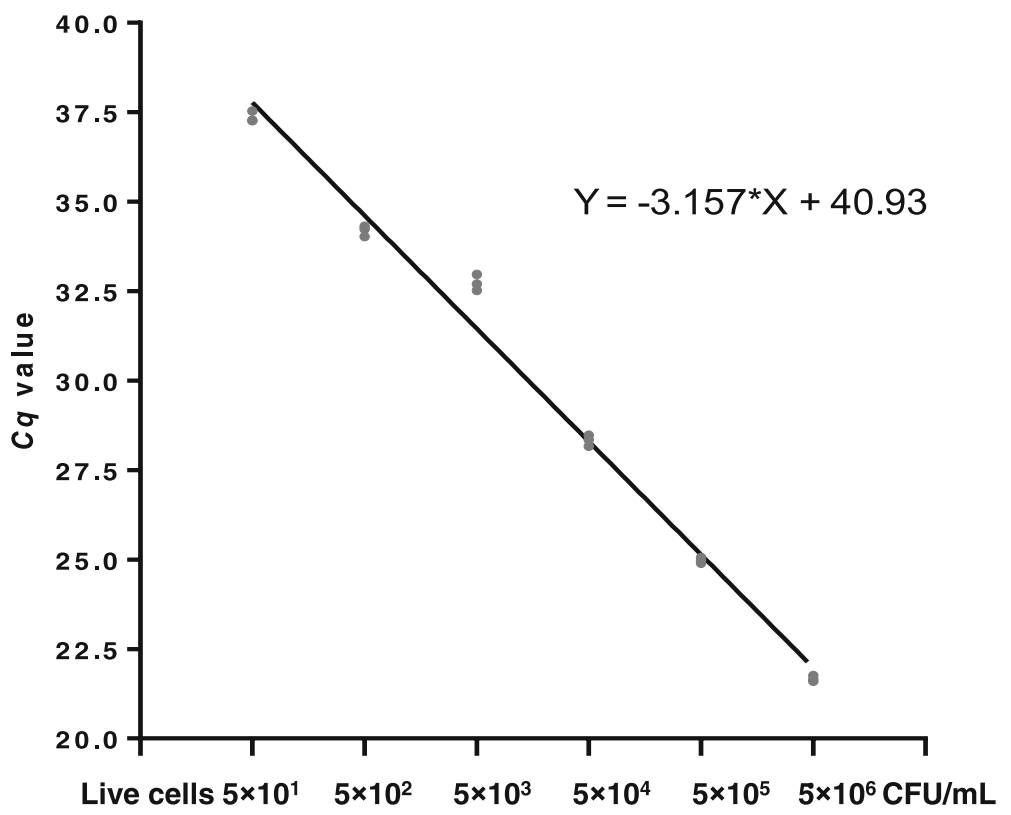

Fig. 1 Performance of detection of $S$. aureus by the qPCR assay. The standard curve showed a $R^{2}$ of 0.99 , a slope of -3.16 , and an amplification efficiency of $100.36 \%$. The $C q$ values of serially diluted cell suspensions $\left(5.0 \times 10^{7}, 5.0 \times 10^{6}, 5.0 \times 10^{5}, 5.0 \times 10^{4}, 5.0 \times 10^{3}, 5.0 \times 10^{2}, 5.0 \times 10^{1}\right)$, indicating a LOD of $5.0 \times 10^{1}$ S. aureus cells with a Cq value of 37.36

2). Based on these data, $0.5 \%$ triton $x-100$ and $0.025 \%$ sarkosyl should be chosen for sample treatment.

\section{Optimization of the PMA concentration for cell treatment}

The PMA-qPCR results showed similar trends between the dead $S$. aureus cells treated with PMA in conjunction with treatment of triton $\mathrm{x}-100$ or sarkosyl (Table 3). In general, the higher concentrations of PMA, the more efficient in preventing amplification of the DNA of dead cells. As the PMA concentration increased, the $\mathrm{Cq}$ values of the dead cells went higher (higher removal efficiency of dead cell DNA). The groups treated with triton $\mathrm{x}-100$ or sarkosyl showed significantly higher $C q$ values (about 2 $\mathrm{Cq}$ values) compared with the control group (PBS) as shown in Table 3. Between the two groups treated with triton $\mathrm{x}-100$ or sarkosyl, the $C q$ values of the sarkosyl-treated group were higher than those of the triton $\mathrm{x}$-100-treated group with high concentration of PMA $(>10 \mu \mathrm{M})$. For the viable cells, on the other hand, the $C q$ values of the triton-treated samples were significantly lower than those of the sarkosyltreated samples, except for the $100 \mu \mathrm{M}$ PMA treatment (Table 4), suggesting sample treatment with triton $\mathrm{x}-100$ is milder to viable cells compared to sample treatment with sarkosyl. Based on the result of triton $\mathrm{x}-100$ treatment, the $C q$ value of $40 \mu \mathrm{M}$ PMA treated sample was significantly higher than the $C q$ values of the samples treated with PMA of $4 \mu \mathrm{M}$ or $10 \mu \mathrm{M}$. However, there were no significant differences between $4 \mu \mathrm{M}$ and $10 \mu \mathrm{M}$, nor between $40 \mu \mathrm{M}$ and $100 \mu \mathrm{M}$ (Table 3). Hence, we chose $40 \mu \mathrm{M}$ of PMA for the optimal concentration in this study.

Table 3 Influence of the treatment of sarkosyl or triton $x-100$ on the removal efficiency of the DNA of dead cells in the PMA-qPCR assay

\begin{tabular}{llll}
\hline PMA concentration $(\mu \mathrm{M})$ & Sarkosyl $(0.025 \%)$ & Triton $\times-100(0.5 \%)$ & PBS \\
\hline 4 & $\mathbf{3 1 . 6 8} \pm \mathbf{0 . 3 5 ^ { \mathrm { ab } }}$ & $\mathbf{3 2 . 5 3} \pm \mathbf{0 . 2 0}$ & $\mathbf{2 9 . 9 4 \pm 0 . 3 3}$ \\
10 & $33.40 \pm 0.49$ & $33.13 \pm 0.56$ & $32.58 \pm 0.19$ \\
40 & $34.38 \pm 0.46$ & $33.64 \pm 0.43$ & $32.31 \pm 0.31$ \\
100 & $\mathbf{3 4 . 8 8} \pm \mathbf{0 . 4 6}$ & $\mathbf{3 3 . 8 8} \pm \mathbf{0 . 3 4}$ & $33.20 \pm 0.13$ \\
$N C^{c}$ & $30.52 \pm 0.52$ & $29.79 \pm 0.42$ & $28.65 \pm 0.35$ \\
\hline
\end{tabular}

${ }^{a}$ refers to the mean Cq value of triplicate \pm standard deviation

${ }^{b}$ bold-faced number refers to a value of a sample treated with the same concentration of PMA that demonstrated a significant difference ( $\left.p<0.05\right)$ between the two surfactants used

crefers to negative controls, which were treated only with surfactant or PBS but without PMA 
Table 4 The combination effect of the treatments of PMA with triton $x-100$ or sarkosyl on live $S$. aureus cells assessed by qPCR

\begin{tabular}{lll}
\hline PMA concentration $(\mu \mathrm{M})$ & Triton $x-100(0.5 \%)$ & Sarkosyl $(0.025 \%)$ \\
\hline 1 & $27.33 \pm 0.12^{\mathrm{a}}$ & $28.64 \pm 0.13$ \\
4 & $\mathbf{2 7 . 9 4} \pm \mathbf{0 . 0 4}$ & $\mathbf{2 9 . 1 0} \pm \mathbf{0 . 0 4}$ \\
10 & $\mathbf{2 7 . 7 1} \pm \mathbf{0 . 2 5}$ & $\mathbf{2 9 . 6 5} \pm \mathbf{0 . 3 4}$ \\
40 & $\mathbf{2 7 . 9 4} \pm \mathbf{0 . 0 4}$ & $\mathbf{2 9 . 5 4} \pm \mathbf{0 . 4 0}$ \\
100 & $28.76 \pm 0.13$ & $28.64 \pm 0.13$ \\
$\mathrm{NC}^{c}$ & $\mathbf{2 3 . 1 5} \pm \mathbf{0 . 1 0}$ & $\mathbf{2 6 . 2 4} \pm \mathbf{0 . 0 9}$
\end{tabular}

${ }^{a}$ refers to the mean Cqvalue of the triplicates \pm standard deviation bold-faced number refers to a value of a sample treated with the same concentration of PMA that demonstrated a significant difference $(p<0.05)$ between the two surfactants used

${ }^{\mathrm{N}} \mathrm{NC}$ refers to a negative control that was treated only with a surfactant but no PMA treatment

\section{Detection of the live cells in live and dead cell} mixture

The result of PMA-qPCR demonstrated a trend that the $C q$ values were getting lower in proportion with the increase of the viable cells after treated with triton $\mathrm{x}-100$ and PMA in the presence of a large number of dead cells (Fig. 2). For instance, two samples (dead cells only; and dead cells with $10^{2}$ viable cells/ $\mathrm{ml}$ ) treated with or without PMA demonstrated drastic differences in the PMA-qPCR result, i.e., the PMA-treat samples showed $C q$ values of approximately 38 and 32; whereas the two samples when were not treated with PMA both generated $C q$ values approximately 25 (Fig. 2). These results indicated that the PMA-qPCR assay developed in this study is able to differentiate the DNA from dead cells and live cells and thus it can accurately reflect the number of live cells.

\section{Detection of viable S. aureus in milk}

In the presence of a large number of dead cells $\left(10^{4} \mathrm{CFU} / \mathrm{ml}\right)$, the inoculated live $S$. aureus cells $\left(10^{2}\right.$, $10^{3}, 10^{4}, 10^{5}$, and $\left.10^{6} \mathrm{CFU} / \mathrm{ml}\right)$ were quantitively detected as shown in Fig. 3. The PMA-qPCR assay demonstrated that the DNA from dead cells was completely excluded from PCR amplification and the limit of detection (LOD) of the assay reached $10^{2} \mathrm{CFU} / \mathrm{ml}$ of $S$. aureus in spiked milk.

\section{Discussion}

PCR is a useful tool for rapid detection of foodborne pathogens, however, its inability to differentiate DNA from dead cells and live cells in amplification severely limits its application in pathogen detection [7]. To overcome this drawback of PCR, a novel approach has been taken to prevent the amplification of DNA of dead cells. DNA intercalating dyes biological dies, EMA and PMA, were used to pretreat samples before DNA extraction to remove the DNA of dead cells $[14,15]$. EMA can effectively penetrate dead cells and to some degree penetrate viable cells [16], whereas PMA does not significantly inhibit PCR amplification of DNA of viable cells [14, 17]. In this study, we evaluated the capability and suitability of two surfactants (triton $\mathrm{x}-100$ and sarkosyl) in enhancing PMA's permeability to dead cells to improve the efficiency of accurate detection of the DNA of live cells by incorporating treatments of PMA and surfactant in a qPCR assay.

Previously, sarkosyl has been used to increase PMA's penetration to the dead cells and found that $0.3 \%$ sarkosyl significantly affected the viability of $S$. aureus [12]. In this study, it was also found that the viability of $S$. aureus was affected by $0.25 \%$ sarkosyl, and it can be affected

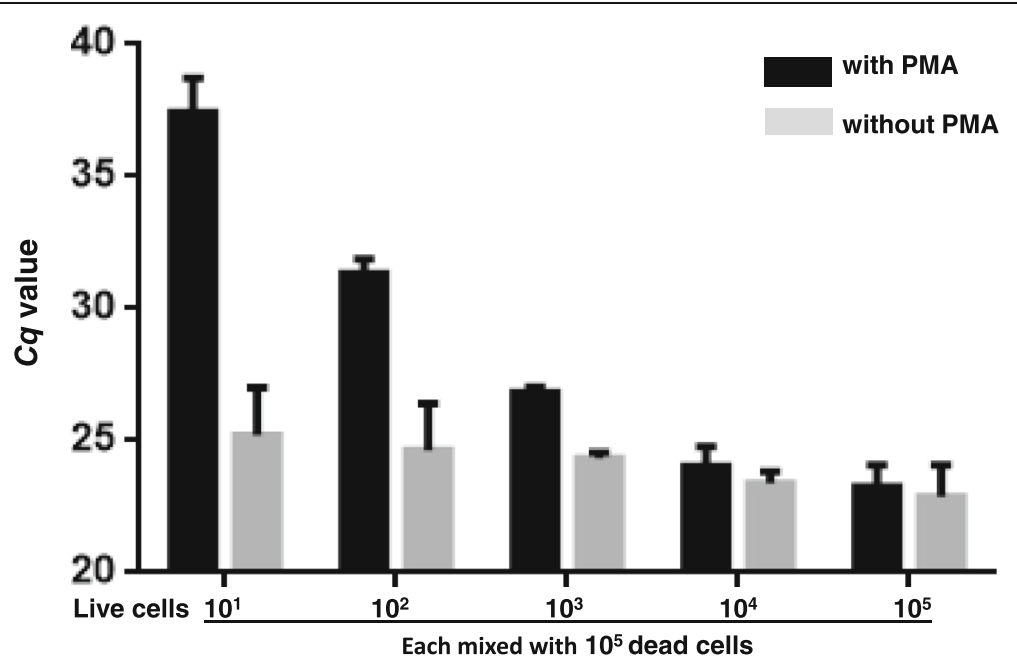

Fig. 2 Detection of viable cells of S. aureus in the presence of a large number of dead cells by the PMA-qPCR. The numbers on the $X$ axis (1-5) represent the number of live cells in the samples $\left(0,1.0 \times 10^{2}, 5.0 \times 10^{3}, 1.0 \times 10^{4}\right.$, and $2.0 \times 10^{5} \mathrm{CFU} / \mathrm{ml}$, respectively), mixed with $2.0 \times 10^{5} \mathrm{CFU} / \mathrm{ml}$ dead cells 


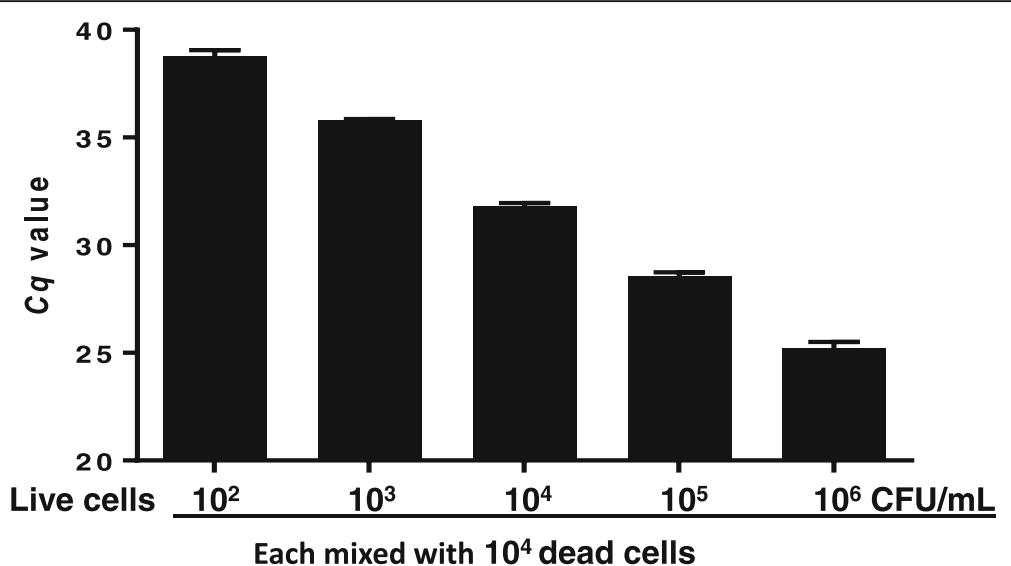

Fig. 3 Detection of viable S. aureus cells in spiked milk samples by the PMA-qPCR assay. All milk samples (1 ml) were mixed with $10^{4}$ dead S. aureus cells, and then each sample was mixed with a different number of live $S$. aureus cells $\left(10^{2}, 10^{3}, 10^{4}, 10^{5}\right.$, and $10^{6}$ CFU/ml), respectively. Each concentration of cell was sampled in triplicate

more severely by higher concentrations. Comparatively, $S$. aureus cells demonstrated tolerance to a broader range of concentrations of triton $\mathrm{x}-100$, suggesting triton $\mathrm{x}-100$ is milder surfactant to live $S$. aureus cells and in the men time it can facilitate PMA's penetration to the cell membranes of dead cells.

The analysis on the toxic effect of the two surfactants showed that $0.5 \%$ triton $\mathrm{x}-100$ or $0.025 \%$ sarkosyl virtually did not affect the viability of the live cells. The use of $0.5 \%$ triton $\mathrm{x}-100$ or $0.025 \%$ sarkosyl in the dead cells prior to PMA treatment achieved much higher $C q$ values compared to the PBS control, indicating the two surfactants helped PMA penetrate the cell membranes of the dead cells, which led to a more complete removal of DNA of the dead cells. On the other hand, when the treatment of surfactants was combined with PMA, the synergy of the treatments did show some affect to the viability of the live cells compared to the cells treated with PMA and PBS; and the treatment of PMA with sarkosyl affected live cells more severely than with triton $\mathrm{x}-100$, suggesting $S$. aureus is more sensitive to the treatment of PMA with sarkosyl than PMA with triton $\mathrm{x}-100$, in other words, treatment of PMA and triton $\mathrm{x}-100$ was gentler to $S$. aureus cells than PMA and sarkosyl. According to the result of the three groups $(0.5 \%$ triton $x-100,0.025 \%$ sarkosyl and PBS), optimized PMA treatment concentration was $40 \mu \mathrm{M}$, which was same used by Dong et al. [18]. Taking together, sample treatment of PMA and triton $\mathrm{x}-100$ is more advantageous for dead cell DNA removal in qPCR. Hence, we chose the combination of PMA $(40 \mu \mathrm{M})$ and triton $\mathrm{x}-100(0.5 \%)$ for sample treatment in the detection of live $S$. aureus cells in spiked milk.

The ability of the PMA-qPCR to accurately detect live cells was validated by the application this assay to spiked milk. It showed that the assay reached the LOD of
$10^{2} \mathrm{CFU} / \mathrm{ml}$, which is compatible to a previous report, in which a qPCR assay showed a LOD of $3.0 \times 10^{2} \mathrm{CFU} / \mathrm{g}$ in spiked milk powder [19]. Furthermore, in the inclusivity and exclusivity testing, the $S$. aureus strains tested $(n=21)$ were positively detected by the qPCR assay and none of the non-S. aureus strains tested $(n=30)$ showed cross-reactivity (Table 1). Thus, our data confirmed that the PMA-qPCR assay developed in this study is sensitive, specific, and accurate for detection of S. aureus in food. Also, the information on selection of appropriate surfactant for improving PMA's dead cell DNA removal efficiency is useful, and it can be used for detection of other pathogens as well, particularly pertinent to Gram-positive pathogens.

\section{Conclusions}

In this study, we developed a qPCR assay in conjunction with treatments of PMA and surfactants. This assay offers a sensitive and accurate means for detection of viable S. aureus cells. Cell toxic effect testing with the two surfactants showed that the viability of $S$. aureus was virtually not affected by the treatment with $0.5 \%$ triton $\mathrm{x}-100$ or $0.025 \%$ sarkosyl. The PMA-qPCR results indicated that the assay reached high an amplification efficiency and the live $S$. aureus cells were accurately detected from the triton-treated spiked milk samples. Additionally, the information on cell sample treatment with surfactants to improve the dead cell DNA removal efficiency in qPCR by increasing PMA's permeability to dead cells can be used for other pathogens, especially for Gram-positive bacteria.

\section{Abbreviations}

DNA: Deoxyribonucleic acid; EMA: Ethidium monoazide; GLM: General Linear Model; LB: Luria Bertani; LOD: Limit of detection; MRSA: Methicillin-resistant Staphylococcus aureus; NC: Negative control; PBS: Phosphate buffered saline; PCR: Polymerase chain reaction; PMA: Propidium monoazide; WHO: World Health Organization 


\section{Funding}

This study, including the design of the study and collection, analysis, and interpretation of data and in writing the manuscript, was funded by the National Key Research and Development Program of China (2017YFF0208600), Jiangsu Agricultural Independent Innovation Project SCX (18) 2011, The National "Youth Top-notch Talent" Support Program (W0270187), Introduction of Nanjing Agricultural University Scientific Research Grants Project (804121), Central Guidance for Local Science and Technology Development (No. YDZX20173100004528), Science and Technology Joint Project of the Yangzte River Delta (No.17395810102), Jiangsu Collaborative Innovation Center of Meat Production and Processing.

\section{Availability of data and materials}

The datasets used and/or analyzed during the current study are available from the corresponding authors on reasonable request.

\section{Authors' contributions}

FX and YJ conceived the project. CZ and DZ performed the experiments. $J Z, J D$, and $B L$ analyzed the data. $C Z, D Z$, and BL wrote the manuscript. All authors read and approved the manuscript.

\section{Ethics approval and consent to participate}

Not applicable.

\section{Consent for publication}

Not applicable.

\section{Competing interests}

The authors declare that they have no competing interests.

\section{Publisher's Note}

Springer Nature remains neutral with regard to jurisdictional claims in published maps and institutional affiliations.

\section{Author details}

MOE Joint International Research Laboratory of Animal Health and Food Safety, College of Veterinary Medicine, Nanjing Agricultural University, Nanjing 210095, China. ${ }^{2}$ Shanghai Entry-Exit Inspection and Quarantine Bureau, Shanghai 200135, China. ${ }^{3}$ Division of Molecular Biology, Center for Food Safety and Applied Nutrition, U.S. Food and Drug Administration, Laurel, MD 20708, USA.

Received: 27 April 2018 Accepted: 27 September 2018

Published online: 11 October 2018

\section{References}

1. Fournier B, Philpott DJ. Recognition of Staphylococcus aureus by the innate immune system. Clin Microbiol Rev. 2005;18(3):521-40.

2. Mehtar S. The continuing problem of 'hospital staphylococci': why? J Chemother. 1994;6(Suppl 4):25-31 discussion 39-40.

3. Shin E, Hong H, Park J, Oh Y, Jung J, Lee Y. Characterization of Staphylococcus aureus faecal isolates associated with food-borne disease in Korea. J Appl Microbiol. 2016;121(1):277-86.

4. Weese JS, Avery BP, Reid-Smith RJ. Detection and quantification of methicillin-resistant Staphylococcus aureus (MRSA) clones in retail meat products. Lett Appl Microbiol. 2010;51(3):338-42.

5. WHO. Antimicrobial Resistance: Global Report on Surveillance. Geneva: World Health Organization; 2014

6. Masters $\mathrm{Cl}$, Shallcross JA, Mackey BM. Effect of stress treatments on the detection of Listeria monocytogenes and enterotoxigenic Escherichia coli by the polymerase chain reaction. J Appl Bacteriol. 1994;77(1):73-9.

7. Zeng D, Chen Z, Jiang Y, Xue F, Li B. Advances and challenges in viability detection of foodborne pathogens. Front Microbiol. 2016;7:1833.

8. Yang X, Badoni M, Gill CO. Use of propidium monoazide and quantitative PCR for differentiation of viable Escherichia coli from E. coli killed by mild or pasteurizing heat treatments. Food Microbiol. 2011;28(8):1478-82.

9. Nocker A, Mazza A, Masson L, Camper AK, Brousseau R. Selective detection of live bacteria combining propidium monoazide sample treatment with microarray technology. J Microbiol Methods. 2009;76(3):253-61.
10. Li B, Chen JQ. Real-time PCR methodology for selective detection of viable Escherichia coli 0157:H7 cells by targeting Z3276 as a genetic marker. Appl Environ Microbiol. 2012;78(15):5297-304.

11. Kobayashi H, Oethinger M, Tuohy MJ, Hall GS, Bauer TW. Improving clinical significance of PCR: use of propidium monoazide to distinguish viable from dead Staphylococcus aureus and Staphylococcus epidermidis. J Orthop Res. 2009;27(9):1243-7.

12. Li H, Xin H, Li SF. Multiplex PMA-qPCR assay with internal amplification control for simultaneous detection of viable Legionella pneumophila, Salmonella typhimurium, and Staphylococcus aureus in environmental waters. Environ Sci Technol. 2015:49(24):14249-56.

13. Wang $\mathrm{H}$, Gill CO, Yang X. Use of sodium lauroyl sarcosinate (sarkosyl) in viable real-time PCR for enumeration of Escherichia coli. J Microbiol Methods. 2014;98:89-93.

14. Cawthorn DM, Witthuhn RC. Selective PCR detection of viable Enterobacter sakazakii cells utilizing propidium monoazide or ethidium bromide monoazide. J Appl Microbiol. 2008;105(4):1178-85.

15. Chiao TH, Clancy TM, Pinto A, Xi C, Raskin L. Differential resistance of drinking water bacterial populations to monochloramine disinfection. Environ Sci Technol. 2014;48(7):4038-47.

16. Flekna G, Stefanic P, Wagner M, Smulders FJ, Mozina SS, Hein I. Insufficient differentiation of live and dead Campylobacter jejuni and Listeria monocytogenes cells by ethidium monoazide (EMA) compromises EMA/realtime PCR. Res Microbiol. 2007;158(5):405-12.

17. Rueckert A, Ronimus RS, Morgan HW. Rapid differentiation and enumeration of the total, viable vegetative cell and spore content of thermophilic bacilli in milk powders with reference to Anoxybacillus flavithermus. J Appl Microbiol. 2005:99(5):1246-55.

18. Dong L, Liu HM, Meng L, Xing MR, Wang JQ, Wang C, Chen H, Zheng N. Quantitative PCR coupled with sodium dodecyl sulfate and propidium monoazide for detection of viable Staphylococcus aureus in milk. J Dairy Sci. 2018;101(6):4936-43.

19. Zhang Z, Liu W, Xu H, Aguilar ZP, Shah NP, Wei H. Propidium monoazide combined with real-time PCR for selective detection of viable Staphylococcus aureus in milk powder and meat products. J Dairy Sci. 2015; 98(3):1625-33.

\section{Ready to submit your research? Choose BMC and benefit from:}

- fast, convenient online submission

- thorough peer review by experienced researchers in your field

- rapid publication on acceptance

- support for research data, including large and complex data types

- gold Open Access which fosters wider collaboration and increased citations

- maximum visibility for your research: over $100 \mathrm{M}$ website views per year

At $\mathrm{BMC}$, research is always in progress.

Learn more biomedcentral.com/submissions 